\title{
Penggunaan Campuran Serbuk Kerang Lokal Sebagai Pengganti Sebagian Semen Pada Pembuatan Beton
}

\section{Use of a Mixture of Local Shellfish Powder as a Partial Replacement for Cement in the Concrete Manufacture}

\author{
Subaidillah Fansuri ${ }^{1}$, Anita Intan Nura Diana ${ }^{2}$, Dwi Deshariyanto ${ }^{3}$ \\ ${ }^{1}$ Program Studi Teknik Sipil, Fakultas Teknik, Universitas Wiraraja. J1 Raya Sumenep-Pamekasan Km 5, \\ Patean. Sumenep. Kode Pos 69461. Email : subaidillah.sd@gmail.com \\ ${ }^{2}$ Program Studi Teknik Sipil, Fakultas Teknik, Universitas Wiraraja. Jl Raya Sumenep-Pamekasan Km 5, \\ Patean. Sumenep. Kode Pos 69461. Email : anita@wiraraja.ac.id \\ ${ }^{3}$ Program Studi Teknik Sipil, Fakultas Teknik, Universitas Wiraraja. Jl Raya Sumenep-Pamekasan Km 5, \\ Patean. Sumenep. Kode Pos 69461. Email : dwi@wiraraja.ac.id
}

\begin{abstract}
Abstrak
Pembangunan menggunakan kontruksi beton memiliki banyak keunggulan dibandingkan material struktur lainnya. Sebagai alternatif untuk memanfaatkan limbah di sekitar lingkungan, maka diperlukan penelitian campuran beton menggunakan material lain. Dalam penelitian ini digunakan kulit kerang, sebagai bahan baku utama dalam pembuatan beton, dengan variasi kulit kerang $10 \%$ dan $20 \%$. Penelitian ini dilakukan di laboraturim Fakultas Teknik Universitas Wiraraja Sumenep. Ekperimen pada penelitian ini dilakukan dengan cara membandingkan beton normal $f_{c}=25 \mathrm{Mpa}$ sebagai kontrol, Benda uji tersebut diuji dengan pengujian kuat tekan. Dalam penelitian ini sampel yang akan diuji untuk kuat tekan sebanyak 5 sampel dari setiap masing-masing variasi campuran. penelitian ini menggunakan analisis frekuensi (Distribusi Frekuensi). Dari hasil penelitian yang dieksperimenkan diharapkan mengetahui pengaruh serbuk kulit kerang sebagai pengganti semen terhadap kuat tekan beton. Hasil penelitian menunjukkan beton yang menggunakan penambahan serbuk kulit kerang sebagai pengganti semen mengalami penurunan kuat tekan. Beton normal tanpa penambahan serbuk kulit kerang memiliki kuat tekan karakteristik 20,63 Mpa. Beton dengan serbuk kulit kerang $10 \%$ sebagai pengganti semen tersebut memiliki kuat tekan karakteristik sebesar 14,67 Mpa. Beton dengan serbuk kulit kerang 20\% sebagai pengganti semen memiliki kuat tekan karakteristik sebesar 13,69 Mpa.
\end{abstract}

Kata Kunci: Beto;, kulit kerang; pengganti semen.

\begin{abstract}
Construction using concrete construction has more advantages than other structural materials. As an alternative to the utilization of waste around the environment, it is necessary to research concrete mixtures using other materials. In this study using seashells, as the main raw material in the manufacture of concrete, with variations of seashells $10 \%$ and $20 \%$. This research was conducted at the Laboratory of the Faculty of Engineering, University of Wiraraja Sumenep. Experiments in this study were carried out by comparing the normal concrete $f_{c}=25 \mathrm{MPa}$ as a control, this specimen supports compressive strength testing. In this study the samples to be cited for compressive strength were 5 samples from each mixture variation. This research uses Frequency analysis. From the results of the experiment that is expected to study the effect of clam shell powder as a result of cement on the compressive strength of concrete. The results showed that concrete using the addition of clamshell powder instead of cement had a compressive strength decrease. Normal concrete without the addition of conch shell powder has a characteristic compressive strength of $20.63 \mathrm{Mpa}$. Concrete with 10\% shell powder as a substitute for cement has a characteristic compressive strength of $14.67 \mathrm{Mpa}$. Concrete with $20 \%$ seashell powder instead of cement has a characteristic compressive strength of $13.69 \mathrm{Mpa}$.
\end{abstract}

Keywords: Concrete, cement replacement, seashell. 


\section{PENDAHULUAN}

Pembangunan dalam bidang konstruksi di era modern menunjukkan perkembangan yang sangat pesat, diantaranya dalam pembangunan perumahan, kantor, rumah sakit dan sebagainya. Beton sebagai bahan bangunan sudah lama digunakan dan diterapkan secara luas oleh masyarakat sebab memiliki keunggulan-keunggulan dibanding material struktur lainnya yakni memiliki kekuatan yang baik, tahan api, tahan terhadap perubahan cuaca, serta relatif mudah dalam pengerjaan (Agung, 2015).

Material bangunan dalam satu kesatuan struktur, selain dirancang untuk memikul beban juga dirancang untuk menghadapi pengaruh alami lingkungan serta pengaruh sifat penggunaannya. Beton sebagai material bangunan harus memenuhi kriteria kekuatan dan daya tahan atau keawetan. Beton merupakan campuran antara semen portland atau semen hidrolik lainnya,agregat halus, agregat kasar dan air dengan atau tanpa bahan campuran tambahan membentuk massa padat (Departemen pekerjaan Umum,1989). Bahan-bahan yang ditambahkan kedalam campuran beton pada saat atau selama pencampuran berlangsung, berfungsi untuk mengubah sifat-sifat dari beton agar menjadi lebih cocok untuk pekerjaan tertentu dan menghemat biaya.

Pulau madura sendiri masuk dalam kawasan provinsi Jawa Timur, dan terdapat empat kabupaten di pulau madura. Kabupaten Bangkalan, Sampang, Pamekasan, dan Kabupaten Sumenep. Kabupaten Sumenep yang berada di ujung timur pulau madura terletak di antara $113^{\circ} 32^{\prime} 54^{\prime}$ ' - $116^{\circ} 16^{\prime} 48^{\prime}$ ' bujur timur dan $4^{\circ} 55^{\prime}-7^{\circ} 24^{\prime}$ lintang selatan, luas Kabupaten Sumenep 2.093,457573 km2. Luas wilayah kabupaten Sumenep $\pm 50.000 \mathrm{~km} 2$ dengan jumlah pulau yaitu 126 pulau (data terkoreksi). Panjang pantai $\pm 5577,76 \mathrm{~km}$; jumlah nelayan 30.120 orang; jumlah petani ikan 622 orang; jumlah perahu 7.530 unit dan alat tangkap 30.130 unit. Berdasarkan estimasi produksi potensi sumber daya ikan di perairan laut kabupaten Sumenep Mampu Menghasilkan per tahun sebesar $50.000 \mathrm{~km} 2 \times 4,58$ ton $=229.000$ ton per tahun. sedangkan menurut astimasi potensi sumber lestari dihitung $60 \% \times 229.000$ ton $=137.400$ ton per tahun (Kim, 2012).

Selain potensi memiliki ikan yang cukup banyak, perairan kabupaten Sumenep juga memiliki potensi kerang khususnya di Kecamatan Kalianget. Kerang sebagai sumber protein dan merupakan jenis makanan bersumber dari laut cukup berlimpah, tentunya jumlah kulitnya juga akan sebanding. Selama ini kulit kerang hanya dibuang dan sebagian dari beberpa jenis kerang tertentu kulitnya dikomersilkan untuk bahan dekorasi atau hiasan rumah.

Dalam penelitian ini digunakan kulit kerang, sebagai bahan baku utama dalam pembuatan beton, sehingga bermanfaat dan dapat menurunkan biaya operasional pembuatannya. Kulit kerang mengandung senyawa kimia pozzolan yaitu mengandung zat kapur $(\mathrm{CaO})$, Alumina dan silika sehingga dengan harapan bahwa kulit kerang dapat meningkatkan karakteristik beton. (Siti Maryam, 2006). Penelitian ini bertujuan untuk mengetahui seberapa besar perbandingan kuat tekan antara beton normal dengan beton menggunakan campuran kulit kerang sebagai campuran semen, dengan variasi campuran kulit kerang $10 \%$ dan $20 \%$.

\section{METODE}

Berikut merupakan metode pelaksanaan penelitian yang digambarkan dalam bentuk diagram alir

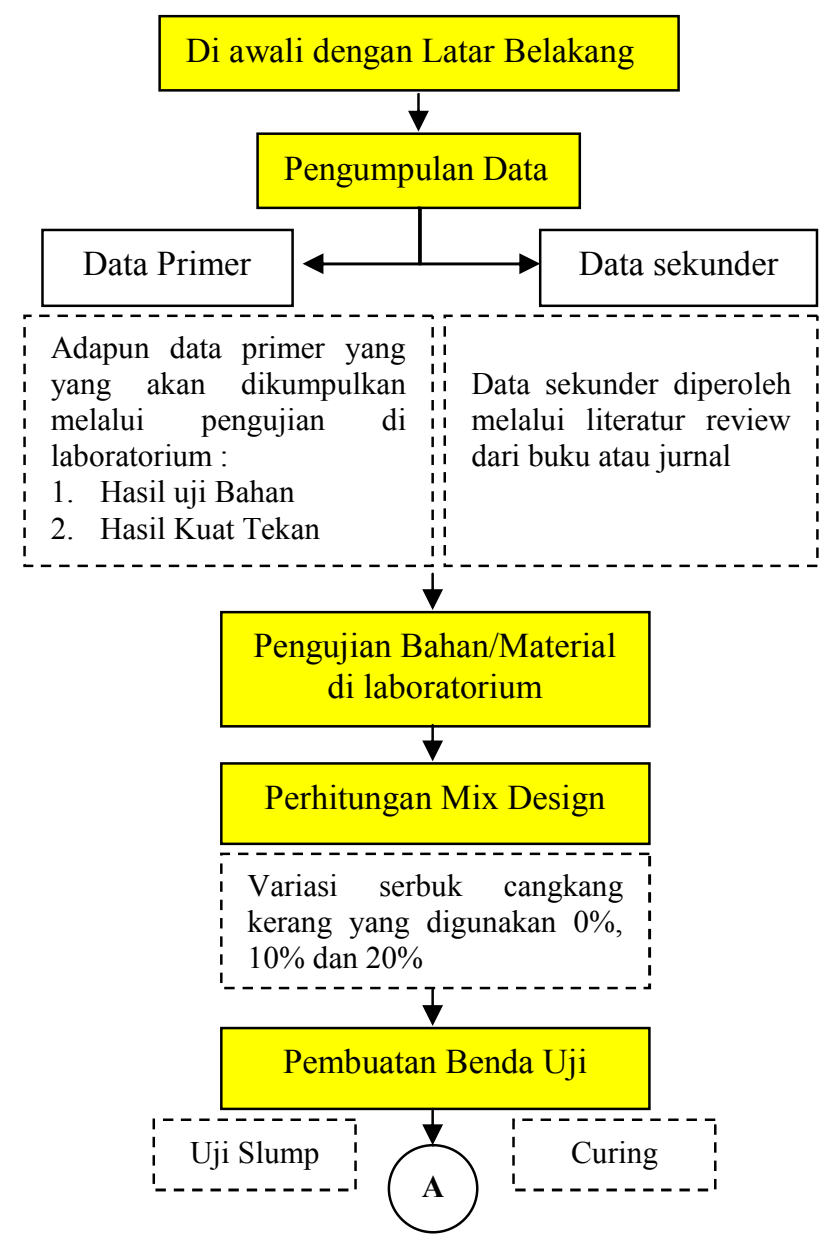




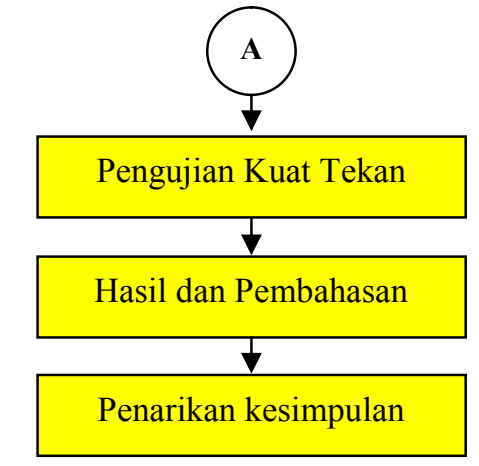

Gambar 1. Diagram Alur Penelitian

\section{HASIL DAN PEMBAHASAN}

Pengujian Bahan Material :

A. Pengujian Agregat Halus

Adapun pengujian agregat halus yang dilakukan yaitu pengujian berat jenis pasir hitam dalam kondisi SSD, pengujian analisis saringan pasir hitam, pengujian modulus kehalusan butir pasir hitam. Berikut hasil pengujiannya :

Tabel 1. Pengujian berat jenis pasir hitam kondisi SSD

\begin{tabular}{lr}
\hline \multicolumn{1}{c}{ PENGUJIAN } & HASIL \\
\hline Berat labu + pasir + air (W1) & $1015 \mathrm{gr}$ \\
Berat pasir SSD (500gr) & $500 \mathrm{gr}$ \\
Berat labu + air (W2) & $696 \mathrm{gr}$ \\
Berat pasir kering oven (W3) & $497 \mathrm{gr}$ \\
Berat jenis kering = W3 $/(\mathrm{W} 3+500-\mathrm{W} 1)$ & $2,74 \mathrm{gr}$ \\
Berat jenis SSD $=500 /(\mathrm{W} 2+500-\mathrm{W} 1)$ & $2,76 \mathrm{gr}$ \\
Berat jenis semu $=\mathrm{W} 3 /(\mathrm{W} 2+\mathrm{W} 3-\mathrm{W} 1)$ & $2,79 \mathrm{gr}$ \\
Penyerapan $=(500 /(500-\mathrm{W} 3)) \times 100 \%$ & $3 \%$ \\
\hline
\end{tabular}

Tabel 2. Pengujian analisa saringan pasir

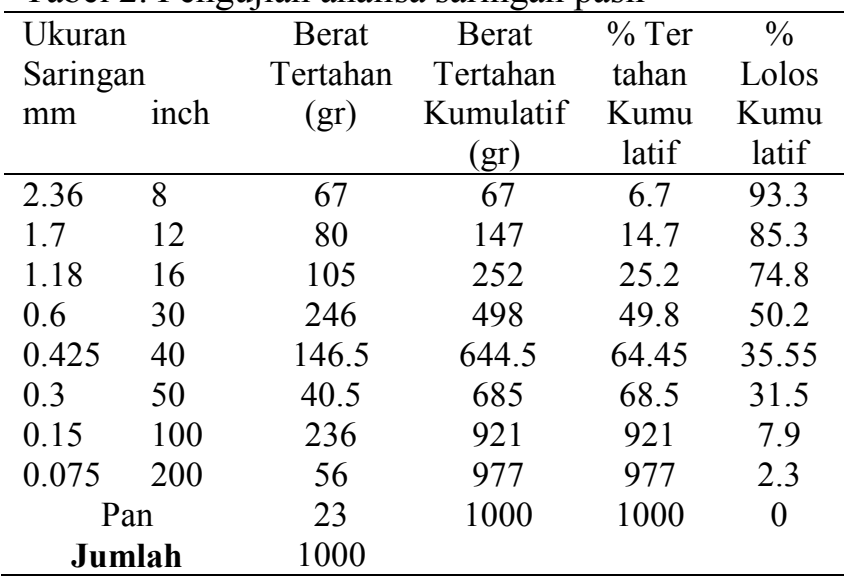

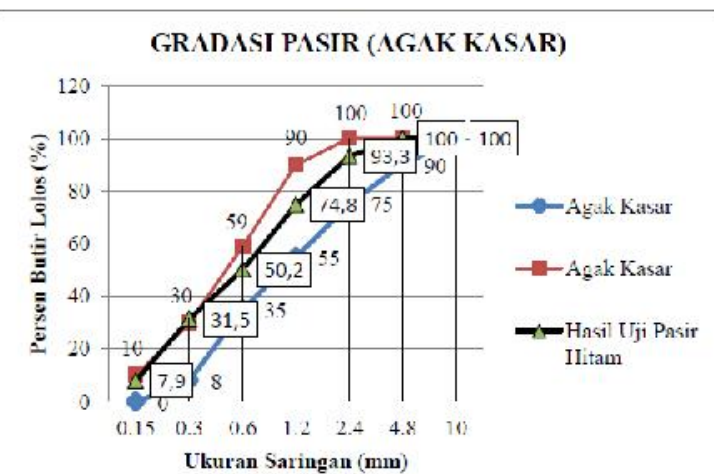

Gambar 2.Grafik Gradasi Pasir Hitam Masuk ke Zona 2

Tabel 3. Modulus kehalusan butir pasir hitam

\begin{tabular}{ccccc}
\hline $\begin{array}{c}\text { Ukuran } \\
\begin{array}{c}\text { Saringan } \\
(\mathrm{mm})\end{array}\end{array}$ & $\begin{array}{c}\text { Berat } \\
\text { Tertahan } \\
\text { (gr) }\end{array}$ & $\begin{array}{c}\text { Berat } \\
\text { Tertahan } \\
\text { Kumulatif } \\
\text { (gr) }\end{array}$ & $\begin{array}{c}\text { \%ertahan } \\
\text { Kumu } \\
\text { latif }\end{array}$ & $\begin{array}{c}\text { \% Lolos } \\
\text { Kumu } \\
\text { latif }\end{array}$ \\
\hline 38 & 0 & 0 & 0 & 100 \\
19 & 0 & 0 & 0 & 100 \\
9.6 & 0 & 0 & 0 & 100 \\
4.8 & 0 & 0 & 0 & 100 \\
2.4 & 67 & 6.7 & 6.7 & 93.3 \\
1.2 & 185 & 18.5 & 25.2 & 74.8 \\
0.6 & 246 & 24.6 & 49.8 & 50.2 \\
0.3 & 187 & 18.7 & 68.5 & 31.5 \\
0.15 & 236 & 23.6 & 92.1 & 7.9 \\
Sisa & 79 & 7.9 & & \\
Jumlah & 1000 & 100 & 242.3 & \\
\hline
\end{tabular}

Modulus kehalusan butir $=\frac{\sum \% \text { tertahan kumulatif }}{100}$ sehingga diperoleh nilai modulus kehalusan butir sebesar 2,423

\section{B. Pengujian Agregat Kasar}

Adapun pengujian agregat kasar yang dilakukan yaitu pengujian berat jenis kerikil lokal dalam kondisi SSD, pengujian kadar air kerikil, pengujian analisis saringan kerikil, pengujian modulus kehalusan butir kerikil. Berikut hasil pengujiannya :

Tabel 4. Pengujian berat jenis agregat kasar

\begin{tabular}{lc}
\hline \multicolumn{1}{c}{ PENGUJIAN } & HASIL \\
\hline Berat benda uji kering permukaan jenuh (W1) & $500 \mathrm{gr}$ \\
Berat ember dalam air (W2) & $590 \mathrm{gr}$ \\
Berat ember + benda uji dalam air (W3) & $896 \mathrm{gr}$ \\
Berat pasir kering oven (W4) & $491 \mathrm{gr}$ \\
Berat jenis kering = W4/ (W2 + W1 - W3) & $2.53 \mathrm{gr}$ \\
Berat jenis SSD = W1/ (W2 + W1 $-\mathrm{W} 3)$ & $2.57 \mathrm{gr}$ \\
Berat jenis semu $=\mathrm{W} 4 /(\mathrm{W} 2+\mathrm{W} 4-\mathrm{W} 3)$ & $2.65 \mathrm{gr}$ \\
Penyerapan $=((\mathrm{W} 1-\mathrm{W} 4) / \mathrm{W} 4) \times 100 \%$ & $1.83 \%$ \\
\hline
\end{tabular}


Tabel 5. Pengujian Kadar Air

\begin{tabular}{lc}
\hline \multicolumn{1}{c}{ PENGUJIAN } & HASIL \\
\hline Berat kerikil asli (W1) & $500 \mathrm{gr}$ \\
\hline Berat kerikil kering oven (W2) & $495 \mathrm{gr}$ \\
\hline Kelembaban kerikil & $(500-459) / 459 \times$ \\
$(\mathrm{W} 1-\mathrm{W} 2) / \mathrm{W} 2 \times 100 \%$ & $100 \%=8.93 \%$ \\
\hline
\end{tabular}

\section{Ukuran Maks, $40 \mathrm{~mm}$}

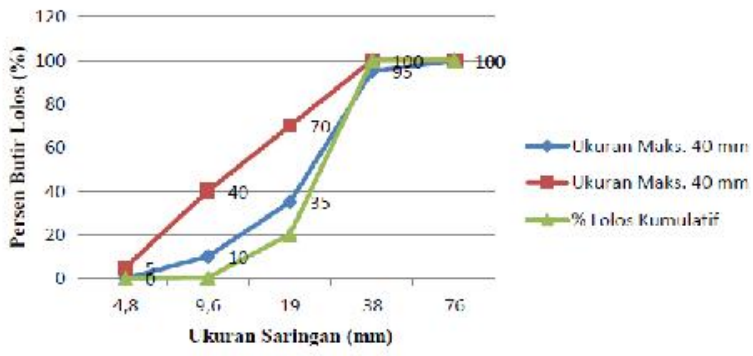

Gambar 3. Grafik Gradasi Agregat Kasar Ukuran Maksimal 40

Tabel 6. Pengujian modulus kehalusan butir agregat kasar

\begin{tabular}{ccccc}
\hline $\begin{array}{c}\text { Ukuran } \\
\text { Saringan } \\
(\mathrm{mm})\end{array}$ & $\begin{array}{c}\text { Berat } \\
\text { Tertahan } \\
(\mathrm{gr})\end{array}$ & $\begin{array}{c}\text { Berat } \\
\text { Tertahan } \\
\text { Kumulatif } \\
\text { (gr) }\end{array}$ & $\begin{array}{c}\% \\
\text { Tertahan } \\
\text { Kumu } \\
\text { latif }\end{array}$ & $\begin{array}{c}\% \text { Lolos } \\
\text { Kumu } \\
\text { latif }\end{array}$ \\
\hline 9.6 & 996.5 & 99.65 & 179.4 & 120.6 \\
4.8 & 0 & 0 & 99.65 & 0.35 \\
2.4 & 3.5 & 0.35 & 100 & 0 \\
1.2 & 0 & 0 & 100 & 0 \\
0.6 & 0 & 0 & 100 & 0 \\
0.3 & 0 & 0 & 100 & 0 \\
0.15 & & 0 & 100 & 0 \\
Sisa & 0 & 0 & & \\
Jumlah & 1000 & 100 & 779.05 & \\
\hline
\end{tabular}

Modulus halus butir (MHB) agregat kasar diperoleh dengan cara yang sama pada agregat halus. Nilai MHB agregat kasar adalah 7,7905.

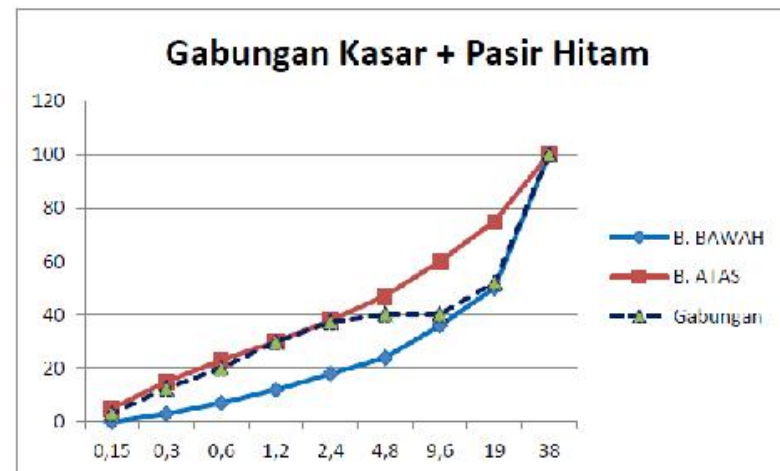

Gambar 4. Grafik Gradasi Gabungan Agregat

Perhitungan proporsi campuran beton dihitung berdasarkan SNI 03-2834-1993 tentang tata cara pembuatan rencana campuran beton normal. Berikut ini hasil perhitungan proporsi campuran beton,
Tabel 7. Proporsi campuran beton variasi serbuk kerang $0 \%$

\begin{tabular}{cccc}
\hline Bahan Jenis & \multicolumn{2}{c}{ Beton serbuk kerang } \\
material & \multicolumn{2}{c}{$0 \%$} \\
& beton & Cam $2 / 5$ & Cam $3 / 5$ \\
\hline Air & $2.06 \mathrm{~kg}$ & $3.09 \mathrm{~kg}$ \\
Semen & $4.06 \mathrm{~kg}$ & $6.102 \mathrm{~kg}$ \\
Agregat kasar & $11.416 \mathrm{~kg}$ & $17.124 \mathrm{~kg}$ \\
Agregat halus & $11.708 \mathrm{~kg}$ & $17.562 \mathrm{~kg}$ \\
Serbuk kerang & $0 \mathrm{~kg}$ & $0 \mathrm{~kg}$ \\
\hline
\end{tabular}

Tabel 8. Proporsi campuran beton variasi serbuk kerang $10 \%$

\begin{tabular}{ccc}
\hline Bahan & Jenis & \multicolumn{2}{c}{ Beton serbuk kerang } \\
beton & \multicolumn{2}{c}{$0 \%$} \\
& Cam $2 / 5$ & Cam $3 / 5$ \\
\hline Air & $2.06 \mathrm{~kg}$ & $3.09 \mathrm{~kg}$ \\
Semen & $3.661 \mathrm{~kg}$ & $5.492 \mathrm{~kg}$ \\
Agregat kasar & $11.416 \mathrm{~kg}$ & $17.124 \mathrm{~kg}$ \\
Agregat halus & $11.708 \mathrm{~kg}$ & $17.562 \mathrm{~kg}$ \\
Serbuk kerang & $0.407 \mathrm{~kg}$ & $0.610 \mathrm{~kg}$ \\
\hline
\end{tabular}

Tabel 9. Proporsi campuran beton variasi serbuk kerang $20 \%$

\begin{tabular}{ccc} 
Bahan & $\begin{array}{c}\text { Jenis } \\
\text { beton }\end{array}$ & \multicolumn{2}{c}{$\begin{array}{c}\text { Beton serbuk kerang } \\
0 \%\end{array}$} \\
& Cam $2 / 5$ & Cam $3 / 5$ \\
\hline Air & $2.06 \mathrm{~kg}$ & $3.09 \mathrm{~kg}$ \\
Semen & $3.255 \mathrm{~kg}$ & $4.881 \mathrm{~kg}$ \\
Agregat kasar & $11.416 \mathrm{~kg}$ & $17.124 \mathrm{~kg}$ \\
Agregat halus & $11.708 \mathrm{~kg}$ & $17.562 \mathrm{~kg}$ \\
Serbuk kerang & $0.804 \mathrm{~kg}$ & $1.220 \mathrm{~kg}$ \\
\hline
\end{tabular}

Pengujian Kuat Tekan Beton

Berikut ini merupakan hasil pengujian kuat tekan dengan menggunakan compressing mechine di Laboratorium Teknik Sipil Unija.

Tabel 9. Hasil kuat tekan dengan variasi serbuk kerang $0 \%$

\begin{tabular}{|c|c|c|c|c|c|c|c|}
\hline \multirow[t]{2}{*}{ No } & \multicolumn{7}{|c|}{ Beton Serbuk Kerang 0\% } \\
\hline & $\begin{array}{c}\text { Berat } \\
\text { (kg) }\end{array}$ & $\begin{array}{c}\text { Koef } \\
\text { umur } \\
21 \\
\text { hari }\end{array}$ & $\begin{array}{c}\text { Beban } \\
\text { maks } \\
(\mathrm{KN})\end{array}$ & $\begin{array}{c}\text { Mutu } \\
\text { rencana } \\
\text { (Mpa) }\end{array}$ & $\begin{array}{l}\text { Kuat } \\
\text { tekan } \\
(\mathrm{Fc})\end{array}$ & $\begin{array}{l}\text { Kuat } \\
\text { tekan } \\
\text { (Fci) }\end{array}$ & $\begin{array}{l}\Sigma \text { (Fci } \\
- \text { Fcir) }\end{array}$ \\
\hline 1 & 12.593 & 0.96 & 405 & & 22.93 & 23.8 & \\
\hline 2 & 12.4 & 0.96 & & 2 & 24.63 & 25.6 & .565 \\
\hline 3 & & 0.96 & & 2 & 21.23 & 22.11 & 1.392 \\
\hline & & 0.9 & & 2 & 22.36 & 23. & 0 \\
\hline 5 & 12.432 & 0.96 & 365 & 25 & 20.66 & 21.52 & 3.132 \\
\hline & & & & 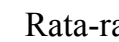 & & 3.2 & \\
\hline
\end{tabular}

Proteksi/ Juni 2020 Volume 2 No. 1 
Tabel 10. Hasil kuat tekan dengan variasi serbuk kerang $10 \%$

\begin{tabular}{|c|c|c|c|c|c|c|c|}
\hline \multirow[t]{2}{*}{ No } & \multicolumn{7}{|c|}{ Beton Serbuk Kerang 10\% } \\
\hline & $\begin{array}{c}\text { Berat } \\
(\mathrm{kg})\end{array}$ & $\begin{array}{l}\text { Koef } \\
\text { umur }\end{array}$ & $\begin{array}{c}\text { Beban } \\
\text { maks } \\
(\mathrm{KN})\end{array}$ & $\begin{array}{c}\text { Mutu } \\
\text { rencana } \\
\text { (Mpa) }\end{array}$ & $\begin{array}{l}\text { Kuat } \\
\text { tekan } \\
(\mathrm{Fc})\end{array}$ & $\begin{array}{l}\text { Kuat } \\
\text { tekan } \\
(\mathrm{Fci})\end{array}$ & $\begin{array}{c}\sum(\text { Fci } \\
- \\
\text { Fcir })^{2}\end{array}$ \\
\hline 1 & 12.469 & 0.96 & 285 & 25 & 16.14 & 16.81 & 1.6179 \\
\hline 2 & 12.177 & 0.96 & 300 & 25 & 16.98 & 17.68 & 0.1616 \\
\hline 3 & 12.29 & 0.96 & 350 & 25 & 19.82 & 20.84 & 7.6065 \\
\hline 4 & 12.048 & 0.96 & 330 & 25 & 18.68 & 19.45 & 1.871 \\
\hline 5 & 12.119 & 0.96 & 265 & 25 & 15.01 & 15.63 & 6.0123 \\
\hline
\end{tabular}

Tabel 11. Hasil kuat tekan dengan variasi serbuk kerang 20\%

\begin{tabular}{|c|c|c|c|c|c|c|c|}
\hline \multirow[t]{2}{*}{ No } & \multicolumn{7}{|c|}{ Beton Serbuk Kerang 20\% } \\
\hline & $\begin{array}{c}\text { Berat } \\
\text { (kg) }\end{array}$ & $\begin{array}{l}\text { Koef } \\
\text { umur }\end{array}$ & $\begin{array}{l}\text { Beban } \\
\text { maks } \\
(\mathrm{KN})\end{array}$ & $\begin{array}{l}\text { Mutu } \\
\text { rencana } \\
\text { (Mpa) }\end{array}$ & $\begin{array}{l}\text { Kuat } \\
\text { tekan } \\
(\mathrm{Fc})\end{array}$ & $\begin{array}{l}\text { Kuat } \\
\text { tekan } \\
\text { (Fci) }\end{array}$ & $\begin{array}{c}\sum(\text { Fci } \\
- \\
\text { Fcir })^{2}\end{array}$ \\
\hline 1 & 11.883 & 0.96 & 240 & 25 & 13.59 & 14.15 & 1.2499 \\
\hline 2 & 11.9 & 0.96 & 260 & 25 & 14.72 & 15.33 & 0.0038 \\
\hline 3 & 12.026 & 0.96 & 275 & 25 & 15.57 & 16.2 & 0.8873 \\
\hline 4 & 12.134 & 0.96 & 245 & 25 & 13.87 & 14.44 & 0.6855 \\
\hline 5 & 11.879 & 0.96 & 275 & 25 & 15.57 & 16.21 & 0.8873 \\
\hline & & & & Rata-ra & ta Fcr & 15.268 & 3.7140 \\
\hline
\end{tabular}

Berdasarkan hasil pada tabel 9, 10, dan 11 menunjukkan penurunan kuat tekan (Fcr). Hal tersebut disebabkan pengaruh variasi pada serbuk kerang yang ditingkatkan dari $0 \%$ menjadi $21 \%$

Tabel 12. Rekapitulasi kuat tekan karakteristik

\begin{tabular}{cccc}
\hline No & $\begin{array}{c}\text { Prosentase Serbuk } \\
\text { Kerang }\end{array}$ & $\begin{array}{c}\text { Mutu } \\
\text { Rencana } \\
(\mathrm{Mpa})\end{array}$ & $\begin{array}{c}\text { Kuat Tekan } \\
\text { Karakteristik } \\
(\mathrm{Mpa})\end{array}$ \\
\hline 1 & $0 \%$ & 25 & 20.63 \\
2 & $10 \%$ & 25 & 14.67 \\
3 & $20 \%$ & 25 & 13.69 \\
\hline
\end{tabular}

Berdasarkan tabel 12 dapat diinformasikan bahwa semakin banyak variasi serbuk kerang yang ditambahkan, maka kuat tekan karakteristiknya semakin rendah.

\section{SIMPULAN}

Berdasarkan hasil penelitian pengaruh campuran bahan pengikat kulit kerang terhadap campuran beton. Hasil uji kuat tekan dengan variasi serbuk kulit kerang 0\% (beton normal) sebesar 20,63 Mpa. Hasil uji kuat tekan untuk variasi serbuk kerang 10\% sebesar 14,67 Mpa. Hasil uji kuat tekan untuk variasi serbuk kerang 20\% sebesar 13,69 Mpa. Berdasarkan hasil uji untuk setiap variasi campuran tidak mencapai pada mutu yang direncanakan yaitu 25 Mpa. Sedangkan kuat tekan karakteristik tanpa serbuk kulit kerang (beton normal) masih lebih tinggi dibandingkan dengan kuat tekan karakteristik beton yang dicampur dengan serbuk kulit kerang sebagai pengganti semen. Maka dapat diketahui bahwa semakin besar penambahan prosentase campuran serbuk kulit kerang terhadap beton maka kuat tekan yang dihasilkan akan semakin rendah.

\section{REFERENSI}

Aji, Purwono. 2010. "Pengendalian Mutu Beton Sesuai SNI, ACI dan ASTM". Surabaya : CV Putra Media Nusantara.

Anonim. 1991. "Tata Cara Recana Pembuatan Campuran Beton Normal", SK SNI T-151990-03. Departemen Pekerjaan Umum, Yayasan LPBM. Bandung.

Departemen Pekerjaan Umum. 2011. "Cara Uji Kuat Tekan Beton dengan Benda Uji Silinder SNI 1974-2011". Badan Standarisasi Nasional

Departemen Pekerjaan Umum. 2002. "Tata Cara Perhitungan Struktur Beton Untuk Bangunan Gedung dengan Standar SK SNI 03-24872002". Badan Standarisasi Nasional.

Departemen Pekerjaan Umum. 2002. "Spesifikasi Agregat Ringan untuk Beton Ringan Struktural SNI 03-2461-2002”. Badan Standarisasi Nasional.

Departemen Pekerjaan Umum. 1971. "Peraturan Beton Bertulang Indonesia (PBI 1971)”. Departemen Pekerjaan Umum, Bandung.

Fansuri, Subaidillah, and Anita Intan Nura Diana. 2018. "Karakteristik Komoditas Batu Kerikil dan Pasir Hitam Untuk Bahan Bangunan di Kabupaten Sumenep". National Conference on Mathematics, Science and Education (NACOMSE). Vol. 1. No. 01. 2018.

Mulyono Tri. 2003. "Teknologi Beton”. Yogyakarta : C.V Andi Offset.

Mehta. P.K. 1986. "Structure, Properties and Material”. Prentice Hall, New Jersey.

Murdock, L.J dan Brook, K.M. 1999. "Bahan dan Praktek Beton”. Edisi keempat, Erlangga, Jakarta.

Nawy, Edward G. 1998. "Beton Bertulang (Suatu Pendekatan Dasar)”. Penerbit PT. Rafika Aditama, Bandung.

Paul Nugraha, Antoni. 2007. "Teknologi Beton”. Penerbit C.V Andi Offset, Yogyakarta

SNI-03-2834-2000. "Tata Cara Pembuatan Rencana Campuran Beton Normal”. Pustran, Balitbang, Departmen Pekerjaan Umum.

Siti Maryam. 2006. "Pengaruh Serbuk Cangkang Kerang Sebagai Filler Terhadap Sifat-Sifat dari Mortar". Skripsi FMIPA. USU

SK.SNI 5-04-1989 F. 1989. "Spesifikasi bahan bagunan A (bukan logam)". Teluk bakau, Gunung Kijang. Spesifikasi Teknik Umum 
SNI-03-2834-1993. 1989. "Tata Cara Pembuatan Rencana Campuran Beton Normal”. Pustran, Balitbang, Departmen Pekerjaan Umum.

Samekto, Wuriyati dan Rahmadianto, Candra. 2001. “Teknologi Beton”. Kanisisus:Yogyakarta.
Tjokrodimuljo, Kardiyono. 2007. "Teknologi Beton”. Biro Penerbit KMTS FT UGM:Yogyakarta. 